\title{
Mod en ny norsk udenrigspolitik
}

\section{Pertti Joenniemi}

\section{Som udenrigsminister har Jonas Gahr Støre konsekvent opfordret sine landsmænd til debat om Norges udenrigspolitik og internationale spørgsmål}

Jonas Gahr Støre: Å gjøre en forskjell. Refleksjoner fra en norsk utenriksminister. Cappelen Damm, 2008. $342 \mathrm{~s}$.

Den udenrigspolitiske debat i Norge er præget af nye strømninger, hvilket fremgår meget tydeligt af Jonas Gahr Støres bog. Det i forvejen mellemstore land er ved at blive væsentligt større både i omfang og i mentalitet. Et væsentligt aspekt ved de nye strømninger er, at begrebet 'globalisering' - hvordan det end opfattes har fået en endnu mere markant position i debatten end i de øvrige nordiske lande. Begrebets stigende centralitet betyder, at Norge konstitueres i en sammenhæng, der tydeligt adskiller sig fra tidligere. Rammen for hvordan landet opfattes udgøres ikke længere primært af billedet om den klassiske nationalstat eller af en kamp, hvor den såkaldte realismes spilleregler anses for at være afgørende. Heller ikke internationalisering eller europæisering anses for at være toneangivende. Den grundlæggende udvikling består derimod angiveligt af en stadig mere dybtgående globalisering.

For at være mere konkret: et Norge der i stigende omfang er relateret til en global energipolitik, shipping, fiskeripolitik, radikalt ændrede klimaforhold, og betydelige ejerskab af investeringsfonde samt en central position i det arktiske problem, er et nyt Norge. De nye rejseruter, der er begyndt at åbne i nord, betyder at Norge langt fra er et land et sted i periferien af Europa, men derimod et potentielt link imellem Europa og Asien.

Forandringerne i udgangspunktet for debatten kommer bl.a. til udtryk 
ved, at den traditionelle forsikring om at den norske udenrigspolitiske linje ligger fast, nu glimrer ved sit fravær. Væk er også det traditionelle fokus på stabilitet og en stræben efter bred enighed. Alt dette har en mindre position i den nuværende diskussion, hvor der i stedet opfordres til en åben og ukonventionel gennemgang af udenrigspolitikkens rammevilkår. Udgangspunktet er ikke længere, som det så ofte var tilfældet tidligere, fasttømret på forhånd, og der er som noget nyt masser af plads til kreativitet og kritisk tænkning.

Det er værd at nævne, at revurderingsprocessen både er institutionaliseret og systematisk. Den omfatter Refleks-projektet som er en grundig gennemgang af norske interesser under de ændrede forhold efter den kolde krig, samt bøgerne - Utenrikspolitikk for en globalisert verden og Mangfold, identitet og utenrikspolitiske utfordringar. Ud over undersøgelser og publikationer består processen af en lang række møder og debatter, som finder sted i forskellige dele af landet. Der er ligeledes blevet tildelt støtte til forskellige organisationer med det formål at engagere og inddrage nye grupper i debatten. Revurderingens sidste fase består af en stortingsmelding (nr. 15) om hovedlinjer $i$ norsk utenrikspolitkk.

Selv den udenrigspolitiske forvaltningskultur er i opblødning: embedsmænd opfordres nu til at tænke højt og skrive frit, og med en stræ- ben efter større åbenhed inkluderer revurderingsprocessen også en række fremtrædende forskere og samfundsdebattører. I bund og grund efterstræbes en dialog mellem det officielle og det civile Norge. Det understreges, at mange af de grundlæggende betingelser for udenrigspolitik er ved at ændre sig, hvorfor Norge får brug for en omfattende og holdbar national evne til at imødegå de udfordringer, som den voksende globale kompleksitet fører med sig.

En central udfordring i forbindelse med globaliseringen er stigende konkurrence. Landet skal udmærke sig - og at opbygge en gavnlig aktiv profil kræver i sig selv en evne til internt samspil imellem stat og samfund. Det er for eksempel nødvendigt, at vidensniveauet om Norge og Norges politikker forbedres (det er fortsat relativt lavt og blandt andet Danmark ligger langt foran på dette punkt). Derudover er det vigtigt for Norge, at landets profil i internationale sammenhænge opfattes som relativt positiv, ukontroversiel og ikke alt for gammeldags.

\section{Synlighed og omdømme}

Går man skridtet videre: I en tid med globalisering udgør synlighed og et positivt omdømme to af udenrigspolitikkens kerneområder. Det er primært i denne eksistentielle og identitetsrelaterede sammenhæng bestående af omverdens værdier, 


\section{LITTERATUR}

idealer og interesser, at 'kampen om Norge' afgøres. Omverdens ofte divergerende opfattelser skal omdannes til en fremtrædende national status og privilegeret position på den internationale scene. Det står klart for den udenrigspolitiske ledelse, at konstitueringen i mødet med omverdenen og via omverdenen ikke altid er lykkedes. Erfaringer har dog øget bevidstheden om, hvad der er vigtigt under de nye omstændigheder.

Mindre problemer, fx i forhold til eksport af fisk til USA og Rusland, har tjent som et wake-up call, men det var især karikaturkrisen - hvor også Norges sårbarhed var helt tydelig - der for alvor satte gang i den kritiske tænkning. De problematiske erfaringer vidner om, at der ikke altid er sammenfald imellem landets internationale omdømme og landets selvbillede. Udfordringerne er kommet som en overraskelse, der har ikke eksisteret en sammenhængende strategi og de budskaber man er gået ud med har langt fra været ensartede og ofte dårligt forankrede i det norske samfund.

Et aspekt af de nye behov består i evnen til at forholde sig til de "nye nordmænd'. Det er vigtigt, at der ikke opstår grupper i udkanten af nationen, grupper som siden hen opfattes eller definerer sig selv som 'andre'. De bør - for ikke at stå udenfor og dermed blive et problem for udenrigspolitikken - inkluderes i og opfattes som et aktiv for den norske nation. Det norske 'vi' kan derfor ikke forblive lukket, selvfølgeligt, og givet én gang for alle. Nationens grænser må derimod ses som fleksible.

Der eksisterer altså et betydeligt behov for udenrigspolitisk formåen på Norges hjemmebane. Den politik der føres, skal have en bred støtte i den hjemlige opinion, og det kræver en bedre forståelse af den kontekst, som man ønsker at beherske.

At en siddende udenrigsminister udgiver en bog rettet primært imod norske læsere, hvor han drøfter centrale og aktuelle emner i den norske udenrigspolitik, er helt i denne ånd.

Støre understreger, at udenrigspolitik, og først og fremmest vanen at tænke udenrigspolitik, bør fornyes. Han antyder, at de etablerede svar ikke nødvendigvis er gyldige og understreger, at det kræver opfindsomhed og engagement, at skærpe den norske opmærksomhed omkring behovet for at skabe en profil. Ministeren tager dermed afstand til tidligere forestillinger - sat på spidsen af udenrigsminister James Løvland i 1905 - om at den bedste udenrigspolitik for småstater er ikke at have nogen politik overhovedet. Alene bogens titel vidner om en helt anden tilgang og et ambitionsniveau, der bestemt ikke bygger på tanken om en politikløs udenrigspolitik.

I bogen bruger Støre sine egne erfaringer som udgangspunkt, men benytter også argumenter, som tidligere er fremført og analyseret i for- 
bindelse med Refleks-projektet. Han tager stilling, kommenterer synspunkter og fører debatten videre. Da rammebetingelserne for norsk udenrigspolitik anses for at være i forandring og der eksisterer en brydningstid for Norge og den norske udenrigspolitik bør det, ifølge ham, undersøges "om kartet vårt må justeras etter nytt terreng".

\section{En ny tids geopolitik}

De geografiske afstandes ændrede betydning belyses konkret i ministerens beskrivelser af sine rejser i Mellemøsten, Afrika og Arktis. Budskabet er, at globaliseringen har en stor indvirkning på, hvordan afstande bør opfattes socialt, sikkerhedsmæssigt og økonomisk inden for rammerne af norsk udenrigspolitik.

Blandt andet energipolitiske interesser - med store norske investeringer og engagement i lande som Saudi-Arabien, Iran, Nigeria, Algeriet og Azerbaisan - betyder, at Norge har fået en ny position på det internationale politiske landkort. Det som tidligere var langt væk og derfor af mindre betydning, er kommet nærmere og er blevet betydningsfuldt. Tilpasning til udvidelsen af nationale interesser - hvor globaliseringen opfattes som en reduktion af territoriets betydning - udgør ifølge Støre en af de største udenrigspolitiske udfordringer. Han efterlyser derfor 'en ny tids geopolitik', dvs. en geopolitik hvor geografi ikke har en på forhånd given betydning.

For at gøre bogen mere tilgængelig og personlig giver han indblik i møder med kolleger fra andre lande. Blandt andre Tony Blair, John Negroponte, Sergei Lavrov, Per Stig Møller og Carl Bildt figurerer i teksten, men Støre fokuserer også på drøftelser med kulturpersonligheder såsom den tyrkiske forfatter Orhan Pamuk om konflikter i forbindelse med kultur, kampen mellem det gamle og det moderne samt Tyrkiets forhold til Europa og Vesten generelt.

Fokus på ændrede omstændigheder og udøvelsen af en ny udenrigspolitik kommer også til udtryk ved, at ministeren giver energipolitik og klima megen plads. De nordlige områder fremstilles i teksten som et livsvigtigt spørgsmål, og problemer i tilknytning til retsstaten, menneskerettigheder, bekæmpelse af fattigdom, fredsskabelse og styrkelse af internationale institutioner er beskrevet som områder, hvor Norge både har vigtige idealpolitiske og realpolitiske interesser at fremme.

Men hvad er forholdet mellem disse to udgangspunkter? Støre understreger, at en idealistisk politik med værdier og idealer som det centrale udgangspunkt ofte forvandles til realpolitik inden for rammen af de nye omstændigheder. Han understreger, at en fokusering på interesser ikke indebærer en nedprioritering af værdier: 'Sådan er det ikke'. En betoning af værdier inden 


\section{LITTERATUR}

for fx rammen af juridiske principper eller minoritetsspørgsmål, kan tværtimod fremstå som en vigtig interesserelateret tilgang.

Den traditionelle opdeling mellem ideelle værdier og realpolitiske interesser har i bund og grund mistet meget af sin tidligere klarhed, hvilket gør det muligt for ministeren kraftigt at understrege betydningen af Norges egne interesser, uden at det lyder som en tilbagevenden til en periode, hvor værdier og interesser ikke blot blev opfattet som to forskellige ting, men også som værende i konflikt med hinanden. Tilsvarende er det blevet muligt at fremhæve, at der lægges vægt på det nationale uden at det umiddelbart kolliderer med et ønske om åbenhed i forhold til det internationale.

\section{Idealister og realister}

I bogen udnyttes disse friheder og nye muligheder fuldt ud. En åben diskussion, hvor Norges interesser ikke tages for givet eller opfattes som naturlige, men kombineres med værdier indebærer at udenrigspolitikken ikke afpolitiseres og præsenteres som en praktisk administration af indlysende mål. Der er al mulig grund til at glæde sig over dette, men det betyder også, at nogle idealister eller for den sags skyld også tilhængere af den realpolitiske skole, kan have problemer med at acceptere de nye toner. De forholdsvis fremtrædende idealister har i Norges til- fælde haft den opfattelse, at interesse er et grimt ord til at begynde med, fordi realisterne mener, at udenrigspolitikken ikke skal blandes sammen med idealisme, moral, etik og værdier.

En del spørgsmål er utvivlsomt vanskelige at besvare. Hvordan kan en høj fredspolitisk profil kombineres med en betydelig eksport af våben og forsvarsmateriel? Hvad er balancen mellem en stærk satsning på udviklingsbistand og beskyttelse af det norske landbrug? Hvordan går eksporten af olie $\mathrm{og}$ gas hånd $\mathrm{i}$ hånd med klimapolitikken? Sat op imod traditionelle opfattelser af udenrigspolitik er ministerens tilgang ikke holdbar. I stedet repræsenterer den for idealisterne eller realisterne politisk retorik.

Men ministeren er sandsynligvis på rette vej: en moderne udenrigspolitik kan næppe være konstrueret uden at værdier knyttes til interesser og at værdier er afgørende for hvordan man definerer sine interesser. I processen er der mange potentielle selvmodsigelser, men i den norske debat synes man at erkende problemerne og være mere åben over for afvejninger end i mange andre lande.

Vil man nødvendigvis rette søgelyset imod bogens mulige svagheder kan man sætte spørgsmålstegn ved relationen mellem norske grundværdier og internationale universelle værdier. Er disse overlappende eller er de vanskelige at forene? Er 
udenrigspolitik et område, hvor nordmændene på grundlag af deres entydige værdier bidrager til udformningen af internationale relationer, eller er der nærmere tale om, at Norge tilpasser sig internationalt dominerende værdier for at Norge, så bredt som muligt, kan blive en del af det internationale samfund og $\emptyset v e$ indflydelse i den sammenhæng? Det er et vanskeligt spørgsmål, som Støre ikke tager op til overvejelse i sit bidrag til debatten.

Selv om viljen til revidering har været bred i den norske debat og har omfattet de fleste politikområder, er sikkerheds-og forsvarspolitik imidlertid en klar undtagelse. Her understreges fortsat betydningen af national samt partipolitisk konsensus og geografiens sædvanlige betydning. Trusselsscenarier har tendens til at være temmelig klassiske, og der er langt mindre fokus på den problematik og de udfordringer, som hænger sammen med globaliseringen og global ustabilitet.

Grunden til afvigelsen og trægheden er uden tvivl, at det der er tilbage af det klassiske Norge netop konstitueres i den sikkerheds- og forsvarspolitiske debat.

Støres bog bryder ikke dette mønster. Han understreger, at generelt med nogle få undtagelser - har samarbejdet med Rusland i det nordlige område været aktivt, uproblematisk og til gavn for begge parter. Samtidig understreger han dog, at Norge fortsat har behov for 'ryggdækning', og der er elementer i bogen, der tyder på, at det nordlige område i stigende grad opleves af forskellige norske beslutningstagere som et område præget af en kamp om interesser. Denne tendens og fortolkning bliver sandsynligvis mødt med stor glæde i den tilsvarende russiske debat, fordi det styrker Ruslands evne til at opretholde - trods globaliseringens udfordringer - det konventionelle selvbillede.

Rusland bidrager uden tvivl med ammunition, der gør det muligt også i den norske debat at klamre sig til opfattelser om klassisk sikkerhedspolitisk sårbarhed, men man kan stille spørgsmålet om, hvor klogt det i sidste ende er at falde for fristelsen.

Den manglende vilje til at tage endelig afsked med det gamle og det traditionelle er imidlertid kun en begrænset del af Støres bog. Hans bidrag viser generelt, at man er kommet langt i analysen af, hvad den kolde krigs afslutning betyder for Norge samt konsekvenserne af at man i stigende grad bliver trukket ind i globale sammenhænge.

Den nationale udvikling af evnen til at relatere sig til de nye udfordringer er sket hurtigt og med en overraskende styrke.

Pertti Joenniemi er seniorforsker ved DIIS (Danish Institute for International Studies). 